\title{
Media memory in the digital world
}

\author{
Denis Artamonov ${ }^{1}$, Marina Volovikova ${ }^{2 *}$, and Sophia Tikhonova ${ }^{1}$ \\ ${ }^{1}$ Saratov State University,410012, Saratov, Russia \\ ${ }^{2}$ Southern Federal University, 344006, Rostov-on-Don, Russia
}

\begin{abstract}
The article analyses how historical memory is being formed in the modern digital realm. The authors show the emergence of a new form of historical memory, characteristic of the digital era, which we call "media memory". Using the methodology historical epistemology, media philosophy and memory studies, the authors demonstrate the change in production and replication of knowledge about the past due to the spread of digital media. The distinctive features of "media memory" are: massive non-professional production of historical content, democratic character, speed, subjectivity and emotional intensity. These features are associated with the combination of prosuming and crowdsourcing, which increase the activity of history lovers and non-professional volunteers in social media. Considering the largest historical digital projects, which have brought together the efforts of millions of history lovers, the article comes to the conclusion that academic historians are losing the monopoly on the production of historical knowledge, while the latter is being turned into digital form, with the widespread participation of ordinary people in the production of such content.
\end{abstract}

\section{Introduction}

Digital media radically transform the social construction of historical memory. Archives and libraries are no longer exclusive institutions for the storage of historical memory, they are giving way to electronic databases. The memory of written culture is losing its ground to electronic memory, which is accessible not only to narrow groups of professionals, but also to the large groups of Internet users.

The latter are actively involved in the process of creating ideas about the past, which was previously managed by professional historians. Collective memory includes a variety of individual images of history. Modern society is experiencing a memory boom associated with the ability of users to produce knowledge about the past and share it via new media. Thus, memory is transferred from the personal and cultural space to the media, which allows us to talk about the emergence of media memory.

The digital revolution has transformed the forms and methods of media communication, giving them a mnemonic function. Media are not simply a storage of information, they

\footnotetext{
* Corresponding author: mvolovikova@yandex.ru
} 
become the tools for creating ideas about the past, and the ways to create historical memory.

\section{Research Method}

The authors used an interdisciplinary approach based on historical epistemology, media philosophy and memory studies. A group of classical methods of formal logic (analysis, synthesis, induction, deduction) was used for categorical analysis. The historical work of prosumers was analyzed as media content by means of media analysis and content analysis, in accordance with the standards of digital philosophy of science and digital humanitarianism [1].

\section{Memory studies and the mediatization of memory}

In traditional society tribal memory served as the instrument of personal identification. It also included social norms of behavior regulation: family traditions, religion, rituals, etiquette, and folklore. All of them served as the basis of collective memory transmitted via the culture of a community. Thus, collective cultural memory was the basis of one's personal intellectual experience and constituted individual memory. The transition from traditional society to industrial one and then to post-industrial and information society was marked by the rupture of tribal ties, and, hence, by the loss of ancestral memory, which marked the emergence of historical memory, storing knowledge not only about the past of individuals and their families, but about the past of peoples and states.

Historical memory is a form of collective memory which serves as the source of information about the past, forming one's identity and worldview. Today historical memory is accumulated in media sphere, which leads to the connection of media as an epistemic tool with the information content they are filled with.

Currently, the study of historical memory has become an independent field of interdisciplinary research. M. Halbwachs has been recognised as the founder of memory research field, he considered memory the product of socialization and participation in communication processes [2]. The legacy of M. Halbwachs was popular in France in the 1980s - early 1990s, when the project "places of memory" was carried out under the supervision of P. Nora [3]. Later these ideas were developed in the works of J. Assman [4], who put forward the thesis that the past is never and nowhere transmitted simply from generation to generation, it is re-created, reconstructed from social reality again and again. J. Fentress and C. Wickham pay special attention to the relationship between individual and collective memory in the social and cultural context [5]. A. Assman's research is devoted to the functioning of historical memory in different social environments and the causes of memory conflicts of our time [6-7]. The impact of digital media on historical and, more generally, social memory is a new problem, which has not been studied thoroughly. The key work in this field is the monograph "Silence, Screen, and Spectacle: Rethinking Social Memory in the Age of Information and New Media", edited by L. Freeman, B. Nenas and R. Daniel in 2014 [8]. The authors note that new social media change the way the present and the past are perceived, analysing the past via the metaphors of "silence", "screen", and "performance".

Memory studies reveal the contribution of ordinary citizens to the formation of historical memory reflected and created by mass culture, art, media environment, school education and research publications. Modern conditions of creation and reproduction of infor- 
mation give the possibility to the large groups of people to be not only consumers of historical knowledge, but also its creators. Internet users are actively involved in the search and replication of knowledge about the past, using modern information technology, Internet resources, social networks, as well as traditional historical sources, turning archival documents into digital format.

In the works of historical epistemologists G. Butterfield, A. Megilla, F. Ankersmit, H. White, R. Koselleck, and N. Koposova history study was associated exclusively with the activity of individual researches, the role of informal knowledge in history research was ignored. Meanwhile, from the point of view of the mass character of the subjects involved, it is possible to distinguish three levels of cognitive activity in the study of history. The first level is the user's historical experience intrinsic to the masses - the real creators of history in the given cultural era. The second level is the way of studying and representation of history, peculiar to the thinkers of the given era, who left some historical sources. The third level is the construction of history, carried out by the professional community of historians.

In the context of this study we are interested in the first level of history studying, because nowadays in the world of modern media this level is changing its structure, technology and methods of production of historical knowledge. Previously, this experience was referred to as the experience of the "silent" majority [9], however, today, due to the new media, this majority has gained a "voice" and plays an increasingly important role in shaping the ideas about the past.

The mediatization of society has led to the formation of a special mechanism of storage, transformation and spread of information, which changed the nature of the production of historical knowledge and its oblivion. The media and social media are becoming as important in creating new understanding of the past as professional historians. The time limits of retention of social information have also changed.

The above mentioned allows us to define media memory as a digital system of storage, transformation, production and dissemination of information about the past, on the basis of which the historical memory of individuals and communities is formed. Media memory can be seen as a virtual social mechanism of remembering and oblivion, it has the ability to provide a variety of forms of history representation in the space of everyday life, to expand the representation and commemoration of the past, as well as to increase the number of people creating and consuming memory content.

\section{Media memory and digital projects creating mass images of the past}

The key characteristic of media memory is the dominance of personal and family memory, forming ideas about the past on the basis of personal emotional experiences which are taken for granted. Biographical evidence and memoirs are of the greatest interest to a modern person, who has the opportunity to share personal history in social media.

Media memory is democratic. It is created on the basis of free expression of thoughts and feelings of people by means of available language. User photographs and documentary evidence play an important role in shaping perceptions of the past, along with subjective perceptions of reality and evaluative statements. Attempts to hide any historical information or to remove it from public access lead to its greater viral distribution. Historical information produced and disseminated by individuals serves their worldview and personal needs, forming one's identity and the picture of the world. Media memory serves as a historical dimension of post-truth, when personal history and personal experience of percep- 
tion of reality replace objective data.

The phenomenon of one's active involvement in the production of information as well as its consumption, is called prosumerism. The term was coined by E. Toffler in "The Third Wave" to describe a mixed form of production and consumption in the labor activity of preindustrial society and the new economy of post-industrial type. Nowadays in the context of mature information societies [10] the term is most often used to characterize the modern process of content and welfare production based on network interaction between producers, consumers and users.

Prosumers are individuals who, according to the "do it yourself" principle, produce a product intended primarily for their own consumption, regardless of whether the production is paid for or not [11]. The ideology of "do it yourself" has a clear counter-cultural character, accumulating the protest against the total commercialization of creativity in a globalizing consumer society. Turning a consumer into a producer, it restores the role of a creator, a free and independent personality, changing the world in accordance with one's plans and projects.

In modern society people have enough free time to spend on producing information or solving common problems, such activities are viewed as entertainment. The use of the resources of large groups of people on the Internet is called crowdsourcing. The term belongs to Jeff Howe, who understood crowdsourcing as the technology of social action, which is based on the delegation of authority to the crowd united on Internet platforms in solving various tasks [12]. The crowd performs creative and intellectual tasks: it produces content, processes scientific materials, develops ideas, evaluates them and chooses the best ones by voting.

Prosuming and crowdsourcing make it possible to overcome the distance between professional historical research and the general public, the latter being involved not only in consumption, but also in the public production of historical knowledge. Currently, public history projects involve a large number of non-professionals who, under professional guidance, carry out the representation of historical knowledge in the forms intended for the general public (museums, art, various kinds of commemoration, television and radio broadcasts, etc.) [13]. These projects fit into the concept of citizen science, which involves groups of volunteers without systematic education and research training. The projects of citizen science, based on the development of digital technologies, are implemented not only in the field of Natural Sciences, but also in the Social Sciences and Humanities, including history (e.g. local history, genealogy and historical reconstruction). They are carried out mainly by enthusiasts and social activists and represent digital participation of citizens in the formation of historical memory. Digital technologies, social networks and Internet platforms modernize the existing forms of non-professional activity, provide a new level of their quality through more effective recruitment of participants, organization of joint work, promotion of historical knowledge and fundraising.

The large online site "Family Tree \& Family History at Geni.com" represents an example of such a project in the field of genealogy, its main purpose is to create a world global family tree with the help of users. Crowdsourcing technologies are successfully used in local history projects, traditionally attracting a large number of non-professional historians who are actively using social networking sites and Internet resources, including Wikipedia, which is the most striking example of crowdsourcing. "Free encyclopedia", created by ordinary users, is one of the most popular, dynamic and accessible online platforms for the aggregation of knowledge, historical knowledge in particular.

Another major crowdsourcing platform for the aggregation of historical content is YouTube, presenting it in video format. The simplest search query on this site by the tag 
"history" gives about 151 million results containing historical films and videos produced not only by TV companies and film studios, but also by ordinary users. YouTube has also become an important platform for promoting the movement of historical reconstruction, hosting more than 189 thousand thematic materials on history. In addition, most of historical clubs and festivals of reconstruction are incorporated into the space of social networks, which provide an opportunity to unite in groups, simplify the process of creating local communities, and contribute to the rapid dissemination of information.

One of the modern forms of historical reconstruction is virtual 3D-modeling, which revives the past via computer technologies. Simplification of software tools today allows any user to recreate the picture of the past in digital models. Another interesting example of virtual simulation of historical reality by users are theme computer games. The principle of open worlds allows players to model their own historical reality within the game, and the spread of indie games, using open source code, allows users to create their own imaginary historical worlds.

Also, the possibility of creating an alternative historical reality is provided by literature (neterature), where writing works in the genre of historical fiction, alternative history, and fantasy has long ceased to be the prerogative of professional writers. The work of famous authors is complemented by their fans, united in fandoms and creating fan fiction - literary texts that continue or modify the main plot of a popular literary or cinematic work. There exists a large number of history lovers among fic writers, and historical plots regularly become the object of their attention.

\section{Conclusion}

The massive spread of Internet technology has led to the emergence of media memory, a new digital form of historical memory. The peculiarity of media memory is the loss of monopoly on the production of historical knowledge by academic historians, turning of historical knowledge into digital form and the widespread participation of users in the creation of such content. Media memory gives historical knowledge a certain selection, including relevant information in the agenda, and being oblivious to something the public doesn't need. There also exists a segmentation of historical knowledge between different elements of the media sphere, which is revealed in a great variety of historical Internet resources for different target audiences. From the standpoint of historical epistemology, we see the emergence of new ways of studying the past. Methodology of historical research and historical sources, previously available only to the professional community of historians are becoming available to an increasing number of people. This leads to the redistribution of historical studies from the scientific community to the common people interested in history. Media memory serves an instrument of such redistribution. The development of media memory becomes a challenge for historical epistemology, as it requires the emergence of completely new approaches that can describe the digital methods of cognition of the past by the groups of individuals, and evaluate them.

Acknowledgements: This work was supported by the Russian Foundation for Basic Researches, the project "The social construction of historical memory in the digital world" (№ 19-011-00265).

\section{References}

1. Ch. H. Pence, Phil. of Science, 5, 930-941 (2018) 
2. M. Halbwachs, Revue Philosophique de Louvain, 12, 497-500 (1926).

3. P. Nora, Rethinking France (University of Chicago Press, Chicago, 2010)

4. J. Assmann, Das Kulturelle Gedächtnis: Schrift, Erinnerung und Politische Identität in Frühen Hochkulturen (Beck, München, 2000)

5. J. Fentress, C. Wickham, Social Memory (Blackwell, Oxford, 1992)

6. A. Assmann, Das Neue Unbehagen an der Erinnerungskultur. Eine Intervention (Beck, München, 2013)

7. A. Assmann, Der Lange Schatten der Vergangenheit. Erinnerungskultur und Geschichtspolitik (Beck, München, 2006)

8. L. A. Freeman, B. Nienass, R. Daniell, Silence, Screen, and Spectacle, N.Y. (Berghahn, Oxford, 2014)

9. N. Bryanik, Epistemology \& Philosophy of Science, 2, 112-129 (2010)

10. L. Floridi, Philos. Technol., 29, 1-4 (2016)

11. N.V. Plotichkina, Herald of RUDN: Sociology, 3, 66-79 (2013)

12. J. Howe, Crowdsourcing (Three Rivers Press, New York, 2009)

13. E.M. Isayev, Herald of Perm University: History, 2, 7-13 (2016) 